\title{
VARTOTOJŲ PASITENKINIMO VIEŠOJO SEKTORIAUS PASLAUGOMIS YPATUMAI
}

\author{
Aistė Diržytė, Aleksandras Patapas \\ Mykolo Romerio universitetas \\ Ateities g. 20, LT-08303 Vilnius, Lietuva \\ doi:10.13165/VPA-13-12-4-03
}

\begin{abstract}
Anotacija. Straipsnyje siekiama atskleisti vartotoju pasitenkinimo viě̌ojo sektoriaus paslaugomis ypatumus, nes vartotoju pasitenkinimas paslaugomis yra vienas iš paslaugu kokybès indikatoriu, ir viešojo sektoriaus organizacijoms labai svarbu žinoti vartotoju pasitenkinimo lygi, kuris gali atspindèti paslaugu kokybę, organizacijos valdymo efektyvuma, gebejima tenkinti konkrečius vartotoju poreikius, taip pat nuo jo gali priklausyti piliečiu pasitikèjimas viešuoju sektoriumi. Šiuolaikiniai autoriai nurodo, jog vartotoju pasitenkinima viešojo sektoriaus paslaugomis gali lemti ne tik paslaugos kokybe, bet ir vartotoju kognityviniai bei asmenybiniai veiksniai. Lietuvoje tokio pobūdžio tyrimai dar nebuvo atliekami, o šiame straipsnyje supažindinama su 2013 metais Lietuvoje atliktu tyrimu (n = 465), kurio tikslas - išsiaiškinti vartotoju pasitenkinimo viě̌ojo sektoriaus paslaugomis ypatumus, vartotoju psichologines charakteristikas, ịvertinti pačiu viešojo sektoriaus institucijų darbuotojų požiūrị i vartotojų pasitenkinimo arba nepasitenkinimo viě̌osiomis paslaugomis priežastis. Tyrimas parodè, kad 10 proc. vartotojų nèra patenkinti viešuju paslaugu kokybe; 9 proc. vartotojų nèra patenkinti viě̌uju paslaugu suteikimo terminais; vartotoju pasitenkinimas paslaugomis ir vartotoju pasitenkinimas paslaugu suteikimo terminais yra statistiškai reikšmingai stipriai susiję $(r=0,611)$; vartotoju samoningumo charakteristikos gali lemti respondentu pasitenkinimo viešosiomis paslaugomis rodiklius; viešuju institucijų darbuotojai nurodo, jog kokybiškai teikti paslaugas gyventojams trukdo šios problemos: mažas etatu skaičius, finansiniu resursu trūkumas, bendras specialistu darbo krūvis; procedūros, pokyčiai, kurie palengvintu viě̌ojo sektoriaus instituciju darbą, teikiant kokybiškas paslaugas gyventojams: mažesnis kiekvienam darbuotojui pavestu užduočiu skaičius, kvalifikacijos kèlimas, bendravimo su interesantais mokymai, etatu skaičiaus didinimas, efektyvesnis informaciniu technologiju naudojimas, platesnis visuomenès informavimas ir švietimas apie viešuju paslaugu vartotoju teises ir pareigas.
\end{abstract}

Raktažodžiai: vartotojų pasitenkinimas, viešosios paslaugos.

Keywords: consumer satisfaction, public services. 


\section{Ivadas}

Vartotojų pasitenkinimas paslaugomis yra vienas iš paslaugų kokybès indikatorių (Ayton, 2007). Viešojo sektoriaus organizacijoms labai svarbu žinoti vartotojų pasitenkinimo lygi, nes jis gali atspindèti paslaugų kokybę (Turchik, 2010), pačios organizacijos valdymo efektyvumą (Hao, 2012), taip pat nuo jo gali priklausyti piliečiu pasitikèjimas viešuoju sektoriumi. Kai kurių autorių teigimu, vartotojų pasitenkinimas paslaugomis parodo, kiek organizacijos sugeba tenkinti konkrečius vartotojų poreikius (Bickman, 2000). Kita vertus, vartotojų pasitenkinimą viešojo sektoriaus paslaugomis gali lemti ne tik paslaugos kokybė, bet ir vartotojų kognityviniai bei asmenybiniai veiksniai, kurių įtaką dar prieš 30 metų pradèjo analizuoti ịvairūs autoriai (pavyzdžiui, Westbrook, 1980). Tyrimų rezultatai gana prieštaringi, nors nustatyta, jog asmenybès bruožai susiję su paslaugų vertinimo predispozicija, pavyzdžiui, paranoidinių bruožų turintys vartotojai linkę mažiau pasitiketi naujomis paslaugomis. Iki šiol vartotojų pasitenkinimo paslaugomis sritis yra plačiai tyrinèjama, siekiant išsiaiškinti pasitenkinimo paslaugomis ir paslaugų kokybės ryšio ypatumus bei atmetant asmenybinius / kognityvinius faktorius kaip samplaikos kintamuosius. Lietuvoje tokio pobūdžio tyrimų iš viso nèra atlikta. Šiame straipsnyje pristatomo tyrimo tikslas - išsiaiškinti vartotojų pasitenkinimo viešojo sektoriaus paslaugomis ypatumus, vartotojų psichologines charakteristikas, taip pat ịvertinti pačių viešojo sektoriaus institucijų darbuotojų požiūrị ị vartotojų pasitenkinimo arba nepasitenkinimo viešosiomis paslaugomis priežastis.

\section{Metodologija}

\section{Tiriamieji}

Apklausoje dalyvavo ir i kiekybinio tyrimo anketos klausimus atsakè iš viso 460 fizinių asmenų; ị kokybinio tyrimo klausimus atsake iš viso 5 viešojo sektoriaus darbuotojai. Jauniausiojo respondento amžius - 18, vyriausiojo - 76 metai. Respondentų amžiaus vidurkis - 41,33 metai, duomenų standartinis nuokrypis - 13,3 metų. Apklausoje dalyvavo 97 vyrai ir 353 moterys. Mažiausias respondentų bendras darbo stažas nesiekia vienerių metų, didžiausias - penkiasdešimt metų. Darbo stažo vidurkis - beveik 18,5 metų, standartinis nuokrypis - 13,1 metų. Gyventojų darbo stažas dabartinèje darbovietėje svyruoja nuo nesiekiančio nè vienerių metų iki 47 metų, darbo stažo dabartinèje darbovieteje vidurkis - 11,2 metu, standartinis nuokrypis - 11,6 metų. 67,8 proc. respondentų nurodè dirbantys viešajame sektoriuje, beveik 26 proc. - privačiame. 47,2 proc. respondentų gyvena santuokoje, 21,1 proc. - nesusituokę, 7,0 proc. - išsiskyrusių, 3,9 proc. - našlių, beveik 4 proc. nurodè gyvenantys su sugyventiniu ir 6,5 proc. - vieni. 46,3 proc. respondentų nurodè, kad yra igiję aukštaji universitetinį išsilavinimą, 13,7 proc. - aukštaji neuniversitetini, 28,3 proc. - aukštesnijji ir 8,7 proc. - vidurini, 0,9 proc. - pradinị. Duomenis apie darbo užmokesti pateikè iš viso 432 respondentai iš 460. Didžioji jų dalis (56,1 proc.) nurode gaunantys nuo 1001 iki 
2000 Lt darbo užmokestị atskaičius mokesčius, beveik 11 proc. gauna didesnị nei $2001 \mathrm{Lt}$ darbo užmokestị atskaičius mokesčius.

\section{Tyrimo metodai}

Tyrimas buvo atliekamas taikant kokybinius ir kiekybinius tyrimo metodus.

Kokybinis tyrimo metodas $(\mathrm{n}=5)$ taikytas tiriant viešojo sektoriaus institucijų darbuotojų požiūrị ị vartotojų pasitenkinimo arba nepasitenkinimo viešosiomis paslaugomis priežastis. Taikant pusiau struktūruoto interviu metodą, viešojo sektoriaus darbuotojams buvo užduoti šie klausimai:

1. Kaip Jums atrodo, kuo šiuo metu Jūsų atstovaujamos viešosios institucijos interesantus tenkina teikiamos paslaugos?

2. Kuo Jūsų atstovaujamos viešosios institucijos interesantai dažniausiai gali būti nepatenkinti?

3. Kaip Jums atrodo, kokios priežastys lemia Jūsų atstovaujamos viešosios institucijos interesantų nepasitenkinimą ir skundus?

4. Kokie sunkumai, kliūtys, problemos trukdo kokybiškai teikti paslaugas gyventojams?

5. Kokios procedūros, pokyčiai palengvintų Jūsų darbą, teikiant kokybiškas paslaugas gyventojams?

Respondentų darbo stažo vidurkis $-8,5$ metų, tai reiškia, kad visi apklausti asmenys turi pakankamai profesinès patirties ir, analizuojant duomenis bei formuluojant praktines rekomendacijas, galima atsižvelgti i jų ekspertines pastabas.

Kiekybinis tyrimo metodas $(\mathrm{n}=460)$ taikytas naudojant straipsnio autorių sukurtą anketą. Respondentams, kurie nurodè esantys viešųų paslaugų vartotojai, buvo užduoti klausimai, skirti įvertinti pasitenkinimą paslaugomis ir jų suteikimo terminais:

1. Kokia viešojo sektoriaus institucijų teikiamų paslaugų kokybè?

2. Kiek tenkina paslaugų suteikimo terminas?

3. Kiek pasitikite viešojo sektoriaus institucijomis?

I klausimus respondentai galëjo atsakyti pasirinkdami vieną iš tyrimo autorių pasiūlytų atsakymų variantų.

Taip pat buvo naudojamos standartizuotos psichologiniu charakteristiku tyrimo metodikos:

1. Situacijų įsisąmoninimo skalė (Brown, K. W., \& Ryan, R. M. (2003), Mindful Attention Awareness Scale).

Šios skalès klausimai skirti įvertinti asmens sąmoningumą, dėmesingumą, suvokimo adekvatumą. Šios skalès teiginių pavyzdžiai:

$\mathrm{P} 1 \mathrm{~b}$ - Aš galiu išgyventi kokią nors emociją ir tik po kurio laiko ją įsisąmoninti.

P1c - Aš ką nors sugadinu ar išbarstau dèl neatidumo, dèl to, kad nekreipiu dèmesio arba galvoju apie ką nors kita. 
Ple - Aš esu linkęs nepastebèti jausmų arba fizinès įtampos ar diskomforto, kol jie tikrai neužvaldo mano dėmesio.

P1g - Atrodo, kad „veikiu automatiškai“, pernelyg neįsisąmonindamas, ką darau.

P1j - Darbus ar veiklas atlieku automatiškai, neįsisąmonindamas, ką darau.

P11 - Nuvykstu ị vietas ,automatiniu pilotu“ ir tada stebiuosi, ko aš ten vykau.

2. Subjektyvios gerovès skalè (Ed Diener (2000), Subjective Well Being Scale).

Šios skalès klausimai skirti ịvertinti asmens pasitenkinimą savo gyvenimu, nes daroma prielaida, kad vartotojai, kurie yra mažiau patenkinti viešojo sektoriaus institucijų paslaugomis, gali būti mažiau patenkinti ir savo gyvenimu apskritai. Šios skalès teiginių pavyzdžiai:

P3 - Esu patenkintas savo gyvenimu.

P4 - Iki šiol man pavyko gauti iš gyvenimo dalykus, kurių norèjau.

Statistiniai duomenys analizuoti naudojant SPSS 19.0 paketą.

\section{Rezultatai}

Siekiant išsiaiškinti, kaip vartotojai vertina viešojo sektoriaus institucijų teikiamu paslaugų kokybę, pateiktas klausimas: „Kokia viešojo sektoriaus institucijų teikiamų paslaugų kokybè?“", i kurị atsakydami vartotojai galëjo pasirinkti vieną iš keturių variantų: 1 - labai prasta, turiu daug nusiskundimų, 2 - prasta, bet tenka su tuo susitaikyti, 3 nežinau, 4 - gera, esu visiškai patenkintas. Kaip matome 1 lentelèje, 2 proc. vartotojų mano, kad viešojo sektoriaus institucijų teikiamų paslaugų kokybė yra labai prasta, tačiau 8,9 proc. yra ịsitikinę, jog ji prasta, 79,3 proc. neturi nuomonès, o beveik 7,4 proc. yra puikios nuomonès ir visiškai patenkinti viešojo sektoriaus institucijų paslaugomis.

\section{1 lentelè. Vartotojų pasitenkinimas viešojo sektoriaus institucijų paslaugomis}

\begin{tabular}{|l|c|c|c|c|}
\hline & Dažnis & Procentai & $\begin{array}{c}\text { Validūs } \\
\text { procentai }\end{array}$ & $\begin{array}{c}\text { Suminiai } \\
\text { procentai }\end{array}$ \\
\hline Labai nepatenkinti & 9 & 2,0 & 2,0 & 2,0 \\
Nepatenkinti & 41 & 8,9 & 9,1 & 11,1 \\
Neturi aiškios nuomonės & 365 & 79,3 & 81.3 & 9,4 \\
Visiškai patenkinti & 34 & 7,4 & 7,6 & 100,0 \\
Trūksta duomenų & 11 & 2,4 & & \\
\hline Iš viso & 460 & 100,0 & & \\
\hline
\end{tabular}

Siekiant išsiaiškinti, ką gyventojai mano apie viešojo sektoriaus institucijų paslaugų suteikimo terminus, respondentams pateiktas klausimas: „Kiek tenkina paslaugų suteikimo terminas?", ị kurị gyventojai galëjo pasirinkti vieną iš keturių atsakymų: 1 - labai prastai vertinu, turiu daug nusiskundimų, 2 - prastai vertinu, bet tenka su tuo susitaikyti, 
3 - nežinau, 4 - gerai vertinu, esu visiškai patenkintas. Kaip matome 2 lentelèje, 0,7 proc. mano, kad viešojo sektoriaus institucijų teikiamų paslaugų suteikimo terminai yra vertintini labai prastai, 8 proc. yra įsitikinę, jog vertintini prastai, beveik 81 proc. neturi aiškios nuomonès, o beveik 7 proc. yra puikios nuomonès ir visiškai patenkinti viešojo sektoriaus institucijų paslaugų suteikimo terminais.

\section{2 lentele. Vartotojų pasitenkinimas viešojo sektoriaus institucijų paslaugų suteikimo terminais}

\begin{tabular}{|l|c|c|c|c|}
\hline & Dažnis & Procentai & $\begin{array}{c}\text { Validūs } \\
\text { procentai }\end{array}$ & $\begin{array}{c}\text { Suminiai } \\
\text { procentai }\end{array}$ \\
\hline Labai nepatenkinti & 3 &, 7 &, 7 &, 7 \\
Nepatenkinti & 37 & 8,0 & 8,3 & 9,0 \\
Neturi aiškios nuomonės & 372 & 80,9 & 83,8 & 92,8 \\
Patenkinti & 32 & 7,0 & 7,2 & 100,0 \\
Trūksta duomenų & 16 & 3,5 & & \\
\hline Iš viso & 460 & 100,0 & & \\
\hline
\end{tabular}

Siekiant išsiaiškinti, ar vartotojai pasitiki viešojo sektoriaus institucijomis, respondentams buvo pateiktas klausimas: „Kiek pasitikite viešojo sektoriaus institucijomis?“,, kurị gyventojai galejo pasirinkti vieną iš keturių atsakymų: 1 - visiškai pasitikiu, 2 - pasitikiu, 3 - nežinau, 4 -nepasitikiu. Kaip matome 3 lentelèje, 26,5 proc. visiškai pasitiki, 52 proc. pasitiki, 15 proc. atsakè „nežinau“, 4,1 proc. nepasitiki viešojo sektoriaus institucijomis.

\section{3 lentelè. Vartotojų pasitikẻjimas viešojo sektoriaus institucijomis}

\begin{tabular}{|l|c|c|c|c|}
\hline & Dažnis & Procentai & $\begin{array}{c}\text { Validūs } \\
\text { procentai }\end{array}$ & $\begin{array}{c}\text { Suminiai } \\
\text { procentai }\end{array}$ \\
\hline Visiškai pasitikiu & 122 & 26,5 & 27,0 & 27,0 \\
Nepatenkinti & 239 & 52,0 & 52,9 & 79,9 \\
Neturi aiškios nuomonės & 71 & 15,4 & 15,7 & 95,6 \\
Patenkinti & 19 & 4,1 & 4,2 & 100,0 \\
Trūksta duomenų & 8 & 1,9 & & \\
\hline Iš viso & 460 & 100,0 & & \\
\hline
\end{tabular}

Siekiant išsiaiškinti ryšį tarp viešojo sektoriaus institucijų paslaugų vartotojų pasitenkinimo pačiomis paslaugomis ir vartotojų pasitenkinimo paslaugų suteikimo terminais, atlikta koreliacinè šių veiksnių analizè, kurios rezultatai pateikti 4 lentelëje. Kaip matome iš 4 lentelès, tyrimas parodè stiprų statistiškai reikšmingą ryšį tarp vartotojų pasitenkinimo paslaugomis ir vartotojų pasitenkinimo paslaugų suteikimo terminais $(r=0,611$, $\mathrm{p}=0,000)$. 


\section{4 lentelé. Vartotojų pasitenkinimo paslaugomis ir pasitenkinimo paslaugų suteikimo terminais koreliacinė analiż}

\begin{tabular}{|c|c|c|c|}
\hline & & $\begin{array}{c}\text { Pasitenkinimas } \\
\text { paslaugomis }\end{array}$ & $\begin{array}{c}\text { Pasitenkinimas } \\
\text { paslaugur suteikimo } \\
\text { terminais }\end{array}$ \\
\hline $\begin{array}{l}\text { Pasitenkinimas } \\
\text { paslaugomis }\end{array}$ & $\begin{array}{l}\text { Pearsono } \\
\text { koreliacija } \\
\text { p reikšmingumas } \\
\text { N }\end{array}$ & $\begin{array}{c}1 \\
449 \\
\end{array}$ & $\begin{array}{l}, 611 * * \\
, 000 \\
438\end{array}$ \\
\hline $\begin{array}{l}\text { Pasitenkinimas } \\
\text { paslaugų suteikimo } \\
\text { terminais }\end{array}$ & $\begin{array}{l}\text { Pearsono } \\
\text { koreliacija } \\
\mathrm{p} \\
\mathrm{N}\end{array}$ & $\begin{array}{l}, 611 * * \\
, 000 \\
438\end{array}$ & 444 \\
\hline
\end{tabular}

** Koreliacija yra reikšminga 0,01 lygiu.

Siekiant suprasti, kaip ịsisąmoninimo lygis susijęs su kitomis psichologinėmis charakteristikomis, buvo atlikta koreliacinè analizè. Kaip matome 5 lentelèje, buvo nustatytas statistiškai reikšmingas ryšys tarp pasitenkinimo gyvenimu ir sąmoningumo, gebejjimo issisąmoninti situacijas $(\mathrm{r}=0,195 ; \mathrm{p}=0,003)$.

\section{5 lentelè. Vartotojų pasitenkinimo gyvenimu ir sąmoningumo koreliacinė analizė}

\begin{tabular}{|ll|c|c|}
\hline & & $\begin{array}{c}\text { Pasitenkinimas } \\
\text { gyvenimu }\end{array}$ & $\begin{array}{c}\text { Sąmoningumas, } \\
\text { gebejjimas } \\
\text { isisąmoninti }\end{array}$ \\
\hline $\begin{array}{l}\text { Pasitenkinimas } \\
\text { gyvenimu }\end{array}$ & $\begin{array}{l}\text { Pearsono } \\
\text { koreliacijos koef. } \\
\text { p reikšmingumas }\end{array}$ & 1 &, $195^{* *}$ \\
$\mathrm{~N}$ & Pearson Correlation &, $195^{* *}$ &, 003 \\
\hline $\begin{array}{l}\text { Sąmoningumas, } \\
\text { gebejjimas } \\
\text { isisąmoninti }\end{array}$ & p reikšmingumas &, 003 & 237 \\
\hline
\end{tabular}

** Koreliacija yra reikšminga 0,01 lygiu.

Lentelèje pateikti rezultatai reiškia, kad kuo sąmoningesnis, labiau įsisąmoninantis asmuo yra įvairiose situacijose, tuo labiau tai gali užtikrinti pasitenkinimą gyvenimu.

Siekiant patikrinti, ar pagal psichologinius kintamuosius galima prognozuoti vartotojų pasitenkinimą paslaugomis, atlikome regresinę analizę, kuri parodè, kaip matyti 6 lente- 
lëje, jog sąmoningumo charakteristikos gali lemti respondentų pasitenkinimo viešosiomis paslaugomis rodiklius.

\section{6 lentelé. Vartotojų psichologinių charakteristikų ir pasitenkinimo paslaugomis regresinė analizè}

\begin{tabular}{|c|c|c|c|c|c|c|}
\hline \multirow{2}{*}{\multicolumn{2}{|c|}{ Modelis }} & \multicolumn{2}{|c|}{$\begin{array}{c}\text { Nestandartizuoti } \\
\text { koeficientai }\end{array}$} & \multirow{2}{*}{$\begin{array}{c}\begin{array}{c}\text { Standardizuoti } \\
\text { koeficientai }\end{array} \\
\text { Beta }\end{array}$} & \multirow{2}{*}{$\mathrm{t}$} & \multirow{2}{*}{ Sig. } \\
\hline & & B & $\begin{array}{l}\text { Std. } \\
\text { Error }\end{array}$ & & & \\
\hline \multirow{3}{*}{1} & (Konstanta) & ,465 &, 131 & & 3,548 & ,000 \\
\hline & Sąmoningumas & 053 &, 029 & ,126 & 1,814 & ,001 \\
\hline & $\begin{array}{l}\text { Pasitenkinimas } \\
\text { gyvenimu }\end{array}$ &,- 021 &, 017 &,- 085 & $-1,227$ & ,221 \\
\hline
\end{tabular}

a. Priklausomas kintamasis: vartotojų pasitenkinimas

Siekiant išsiaiškinti pačių viešojo sektoriaus institucijų darbuotojų požiūrị ị vartotojų pasitenkinimą arba nepasitenkinimą paslaugomis ir tai lemiančius veiksnius, taikytas pusiau struktūruoto interviu metodas ir atlikta viešojo sektoriaus institucijų darbuotojų atsakymų kokybiné analizè. Respondentų vertinimu, viešojo sektoriaus efektyvumą lemia daugelis veiksnių, įskaitant administracinius veiksnius, paslaugų tobulinimą (pavyzdžiui, paslaugų perkèlimas ị elektroninę erdvę, paslaugos suteikimo terminų trumpinimas, kaštų mažinimas ir pan.), o efektyvumą padidintų: etatų skaičiaus didinimas viešojo sektoriaus institucijose, papildomas finansavimas darbuotojų kvalifikacijos kẻlimui, griežtesnès sankcijos už ịstatymų pažeidimus, didesnis dèmesys gyventojų švietimui. Apklausti viešojo sektoriaus institucijų darbuotojai nurodè, jog dabartiniu metu vartotojai gali būti patenkinti paslaugomis, nes: paslaugos yra lengvai prieinamos, nemokamos, galima konsultuotis telefonu, raštu, elektroniniu paštu ar atejjus i pačią instituciją, paslaugos teikiamos profesionaliai, laikomasi teisès aktų nustatytų terminų. Viešojo sektoriaus institucijų darbuotojų manymu, vartotojų nepasitenkinimą ir skundus dažniausiai lemia per ilgas paslaugos suteikimo terminas, kuriam ịtakos turi bendras specialistų darbo krūvis, nors formaliai toks terminas nepažeidžia teisès aktų reikalavimų. I klausimą, kas trukdo kokybiškai teikti paslaugas vartotojams, viešojo sektoriaus institucijų darbuotojai atsakè, jog trukdo šios problemos: per mažas etatų skaičius darbams atlikti, finansinių resursų trūkumas, bendras specialistų darbo krūvis. İ klausimą apie reikalingus pokyčius, teikiant kokybiškas paslaugas gyventojams, viešojo sektoriaus institucijų darbuotojai atsakè, jog procedūros / pokyčiai, kurie palengvintų viešojo sektoriaus institucijų darbą, teikiant kokybiškas paslaugas gyventojams, būtų šie: mažesnis kiekvienam darbuotojui pavestų užduočių skaičius, galimybė kelti kvalifikaciją, bendravimo su piliečiais mokymai, etatų skaičiaus didinimas, efektyvesnis informacinių technologijų naudojimas, platesnis visuomenès informavimas ir švietimas. 


\section{Išvados}

Lietuvoje 2013 metais atlikto tyrimo rezultatai papilde ịvairiose šalyse atliktų tyrimų išvadas apie veiksnius, susijusius su vartotojų pasitenkinimu viešosiomis paslaugomis (Lunnen, 2008; Hao, 2012; Wisniewski, 2001; Chodzaza, 2013; Conroy, 2001; Khurshid, 2012). Analizuojant kiekybinius Lietuvos vartotojų $(n=460)$ ir kokybinius viešųjų institucijų darbuotojų $(\mathrm{n}=5)$ duomenis, nustatyta, kad: 80 proc. vartotojų pasitiki viešosiomis institucijomis; 9 proc. vartotojų nėra patenkinti viešųjų paslaugų suteikimo terminais; 10 proc. vartotojų nėra patenkinti viešųjų paslaugų kokybe; vartotojų pasitenkinimas paslaugomis ir vartotojų pasitenkinimas paslaugų suteikimo terminais yra statistiškai reikšmingai stipriai susiję $(r=0,611)$; vartotojų pasitenkinimas gyvenimu ir sąmoningumas susiję statistiškai reikšmingai, bet silpnai $(\mathrm{r}=0,195)$; vartotojų sąmoningumo charakteristikos gali lemti respondentų pasitenkinimo viešosiomis paslaugomis rodiklius. Viešojo sektoriaus atstovų nuomone, vartotojus gali tenkinti viešujų institucijų teikiamos paslaugos, nes: jos nemokamos, teikiamos profesionaliai, laikomasi teisès aktų nustatytų terminų (gyventojai dèl paslaugų suteikimo gali nemokamai konsultuotis telefonu, raštu, elektroniniu paštu ar atėję i pačią instituciją); vartotojai dažniausiai gali būti nepatenkinti tuomet, jei nori gauti konsultaciją kiek įmanoma greičiau, tačiau specialistai teikia konsultacijas tuoj pat tik telefonu, o el. paštu ar raštu pateikti klausimai atsakomi per tokị terminą, koks nustatytas teisès aktuose; vartotojų nepasitenkinimą ir skundus dažniausiai lemia per ilgas paslaugos suteikimo terminas, kuriam ịtakos turi bendras specialistų darbo krūvis, nors formaliai toks terminas nepažeidžia teisès aktų reikalavimų; kokybiškai teikti paslaugas gyventojams trukdo šios problemos: mažas etatų skaičius, finansinių resursų trūkumas, bendras specialistų darbo krūvis; procedūros, pokyčiai, kurie palengvintų viešojo sektoriaus institucijų darbą, teikiant kokybiškas paslaugas gyventojams: mažesnis kiekvienam darbuotojui pavestų užduočių skaičius, kvalifikacijos kẻlimas, bendravimo su piliečiais mokymai, etatų skaičiaus didinimas, efektyvesnis informacinių technologijų naudojimas, platesnis visuomenès informavimas ir švietimas.

\section{Literatūra}

1. Brown, K. W., Ryan, R. M. The Benefits of Being Present: Mindfulness and its Role in Psychological Well-Being. Journal of Personality and Social Psychology, 2003, 84(4), 822-848.

2. Ed, D., Helliwell, J., Lucas, R., Schimmack, U. (2009). Well-being for Public Policy. Oxford Scholarship Online, April 2010.

3. Diener Ed. Subjective well-being: The Science of Happiness and a Proposal for a National Index. American Psychology, 2000, 55(1), 34-43.

4. Athay, M. M., Bickman, L. Development and Psychometric Evaluation of the Youth and Caregiver Service Satisfaction Scale. Adm Policy Ment Health, 2012, 39: 71-77. 
5. Ayton, A., Mooney, M., Sillifant, K., Powels, J., Rasool, H. The Development of the Child and Adolescent Versions of the Verona Service Satisfaction Scale (CAMHSSS). Social Psychiatry and Psychiatric Epidemiology, 2007, 42, 892-901.

6. Bickman, L. Are you satisfied with Satisfaction? (Editorial). Mental Health Service Research, 2000, 2, 125.

7. Turchik, J. A., Kerpenko, V., Ogles, B. M., Demireva, P., \& Probst, D. R. (2010). Parent and Adolescent Satisfaction with Mental Health Services: Does it relate to Youth Diagnosis, Age, Gender, or Treatment Outcome? Community Mental Health Journal, 46, 282-288.

8. Lunnen, K. M., Ogles, B. M., \& Pappas, L. N. (2008). A Multiperspective Comparison of Satisfaction, Symptomatic Change, Perceived Change and End-point Functioning. Professional Psychology: Research and Practice, 39(2), 145-152.

9. Hao Sun. Study on Model of E-Government Public Satisfaction Based on Service-Oriented. In B. Xu (ed.), 2012 International Conference on Information Technology and Management Science (ICITMS 2012) Proceedings, DOI 10.1007/978-3-642-34910-2 16, Springer-Verlag Berlin Heidelberg, 2013.

10. Westbrook Robert, Consumer Satisfaction as a Function of Personal Competence/ Efficacy. Academy of Marketing Science, Journal of the Academy of Marketing Science, Fall, 1980, Vol. 8, No. 4, 427-437.

11. Wisniewski Mik, (2001) „Using SERVQUAL to assess Customer Satisfaction with Public Sector Services“, Managing Service Quality, Vol. 11 Iss: 6, pp. 380-388.

12. Chodzaza Gilbert E., Harry S.H. Gombachika, (2013) „Service Quality, Customer Satisfaction and Loyalty among Industrial Customers of a Public Electricity Utility in Malawi“, International Journal of Energy Sector Management, Vol. 7 Iss: 2, pp. 269-282

13. Conroy, Denise K. (2001) Customer Satisfaction Measures in the Public Sector: what do they tell us? International Journal of Business Performance Management, 3(2-4), pp. 216-230.

14. Khurshid Rida, Naeem Hummayoun, Ejaz Sana, Mukhtar Faiza, Batool Taha (2012). „Service Quality and Customer Satisfaction in Public Transport Sector“. International Journal of Economics and Management Sciences, Vol. 1, No. 9, pp. 24-30.

Aistė Diržytė, Aleksandras Patapas

\section{Features of Consumer Satisfaction with Public Services}

\section{Abstract}

This paper aims to reveal the features of consumers' satisfaction with public services, as consumers' satisfaction with services is one of the indicators of quality of services in organizations. It is very important to know the level of consumers' satisfaction, which may reflect the quality of services, organizational performance, the ability to meet specific customers' needs, and it might even determine citizens' trust in the public sector. Modern authors indicate that consumers' satisfaction with public services can reflect not only the quality of the services, but also some cognitive and personality factors of consumers. In Lithuania, this kind of research has not been carried out yet before, and this article presents survey $(n=465)$, which was conducted in Lithuania in 2013. The aim of this survey was to find out features of customers' satisfaction with public 
services as well as identify some psychological characteristics of consumers and evaluate the attitudes of public sector employees towards the causes of customers' satisfaction or dissatisfaction. The survey showed that 10 percent of consumers were not satisfied with the quality of public services, 9 percent of consumers were not satisfied with the terms of rendered public services; consumers' satisfaction with the services and consumers' satisfaction with the terms of rendered services are statistically significantly related $(r=0.611)$, consumer awareness characteristics are related to respondents' satisfaction with public services. Public sector employees noted some vulnerable factors that might affect consumers' dissatisfaction: too small a number of staff in public organizations, lack of financial resources, the total workload of specialists. Public sector employees have also proposed some intervention strategies: the less number of tasks assigned to for each employee, human resources training in communication with consumers, more efficient use of information technologies, education of the public service consumers about their rights and responsibilities.

Aiste Diržyte - Mykolo Romerio universiteto Psichologijos instituto docentė, socialinių mokslų daktarè.

E. paštas: aidir@mruni.eu

Aleksandras Patapas - Mykolo Romerio universiteto Politikos ir vadybos fakulteto Viešojo administravimo instituto docentas, humanitarinių mokslų daktaras.

E.paštas: patapas@mruni.eu

Aistė Diržytè, Doctor of Social Sciences, Mykolas Romeris University, Institute of Psychology, Associated Professor.

E-mail: aidir@mruni.eu

Aleksandras Patapas, Doctor of Humanitarian Sciences, Mykolas Romeris University, Institute of Public Administration.

E-mail: patapas@mruni.eu

Straipsnis įteiktas redakcijai 2013 m. spalio 3 d.; recenzuotas; parengtas spaudai $2013 \mathrm{~m}$. spalio mèn. 